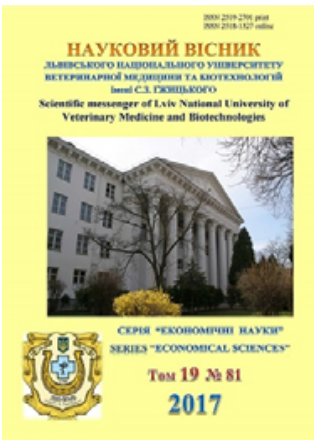

Науковий вісник Львівського національного університету ветеринарної медицини та біотехнологій імені С.3. Гжицького

Scientific Messenger of Lviv National University of Veterinary Medicine and Biotechnologies

doi:10.15421/nvlvet8115

ISSN 2519-2701 print

ISSN 2518-1327 online

http://nvlvet.com.ua/

УДК 338.439.5.339

\title{
Оптові ринки сільськогосподарської продукції як форми підприсмницької діяльності та їх організаційно-правові форми та моделі
}

\author{
Н.А. Доманська \\ domanska.n@icloud.com
}

Львівський національний університет ветеринарної медицини та біотехнологій імені С. 3. Гжиџького, вул. Пекарська, 50, Львів, 79010, Україна

\begin{abstract}
У статті проводиться аналіз відповідності ОРСП як підприємниџького суб'єкта діяльності в світлі Господарського кодексу та Законів України. Розбудова і діяльність ОРСП повинна враховувати економічні та сочіально - правові умови, рівень фінансових ресурсів, а також відсутність в Україні компаній, які мають достатній досвід в розробиі технікоекономічного обтрунтування і організаиї побудови ОРСП згідно з прийнятими європейськими і світовими стандартами. $B$ статті подаються найбільш поширені в світі моделі (механізми) розбудови ринків з участю держсавного та приватного капіталу. В Украӥні прийнятий Закон «Про державно-приватне партнерство», який може бути основоположним в розробиі моделей розбудови і функиіонування ОРСП, але він ще вимагає доопраџювання в сфері розбудови і діяльності мережі ОРСП. Розглядається приклад бізнес-моделі ОРСП.

Ключові слова: оптовий ринок сільськогосподарської продукції, фінансування, інвестиції, підприємство, державноприватне партнерство, моделі ринків, законодавчі акти.
\end{abstract}

\section{Оптовые рынки сельскохозяйственной продукции как формы предпринимательской деятельности и их организационно- правовые формы и модели}

\author{
Н.А. Доманская \\ domanska.n@icloud.com
}

\begin{abstract}
Статья представляет анализ соответсвенности оптового рынка как предпринемательского субьекта в свете Государственного кодекса и Законов Украины. Строительство и деятельность ОРСП долэны учитывать экономические и сочиально-правовые условия в государстве и регионе, уровень финансовых ресурсов, а также отсутствие в Украине компаний, имеющих достаточный опыт в разработке технико-экономического обоснования и строительства ОРСП согласно принятых европейских и мировых стандартов. Рассматриваются наиболее распространенные в мире модели (механизмы) строительства рынков с участием государственного и частного капитала. В Украине принят Закон «O государственно- часном партнерстве», который может быть основополагающим в разроботке моделей строительства и функиионирования ОРСП, но он требует дороботки в сфере строительства и деятельности ОРСП. Наведена рекомендуемая бизнес-модель ОРСП.

Ключевые слова: оптовый рынок сельскохозяйственной продукции, финансирование, инвестиции, государственночастное партнерство, модели рынков, законодательные акты.
\end{abstract}

\section{Wholesale markets of agricultural products as a form of entrepreneurial activity and their organizational and legal forms and models}

\author{
N.A. Domanska
}

\section{Citation:}

Domanska, N.A. (2017). Wholesale markets of agricultural products as a form of entrepreneurial activity and their organizational and legal forms and models. Scientific Messenger LNUVMB, 19(81), 88-92. 
domanska.n@icloud.com

Stepan Gzhytskyi National University of Veterinary Medicine and Biotechnologies Lviv, Pekarska Str., 50, Lviv, 79010, Ukraine

The number of wholesale markets in Ukraine for 10 thousand inhabitants is ten times less than in Western Europe. Wholesale markets for agricultural products (hereinafter referred to as the WMAP) before the transition of Ukraine to market conditions of economic activity were absent and their construction began in the late 90's of the twentieth century. Beginning of the XXI century. Currently, their construction was suspended due to lack of public financial resources. There was a need to attract private capital and investment into the development of WMAP. WMAP as an enterprise of agrarian profile meets all the requirements stipulated by the Commercial Code and Ukrainian legislation. The development and operation of the WMAP should take into account economic and socio-legal conditions. Involving private firms and companies in developing an WMAP network is also appropriate in terms of the quality of market construction. The basis for cooperation between the state and private firms is legislation, in particular, the Law of Ukraine "On public-private partnership». However, it requires some changes and additions concerning the development of the wholesale markets' network. The article presents the most common models (mechanisms) for developing the WMAP network on the basis of public-private partnership. In particular, these are Build, Operate, Transfer, BOOT (Build, Own, Operate, Transfer), BTO (Build, Operate, Transfer), BOO (Build, Own, Operate), BOMT (Build, Operate, Maintain, Transfer, DBOOT, Design, Build, Finance, Operate, DBFO (Design, Build, Finance, Operate) and provides a brief description of them, which involves the involvement of certain partners and their form, for example through concessions (IOT), authority for use and ownership rights, responsibility of a private partner for maintaining the WMAP created by him, including for ongoing repairs (VOMT), the responsibility of a private partner not only for construction but also for its design (DBOOT). The proposed WMAP business model, which includes key partners (international financial organizations and international technical assistance organizations, local and regional administration, sanitary and epidemiological and veterinary services, service organizations). Key activities include infrastructure management, marketing and advertising activities. The main resources are brand, customer database, software, human, financial and logistics. The value proposition includes European standards for wholesale trade, information and consulting support, and stockpile storage. The business model reflects the principles of customer relationships, as well as customer segments, which include farmers and agribusinesses, agro cooperatives, wholesalers, logistics centers. It is expected that in the structure of incomes $50 \%$ will be revenues from the lease of squares in pavilions, 23\% for entry into the territory, $23 \%$ from the lease of space for sale from cars, and $4 \%-$ other services, including advertising.

Key words: wholesale market of agricultural products, financing, investments, state - private partnership, market models, legislative acts.

\section{Вступ}

Оптові ринки сільськогосподарської продукції - це нова форма спеціалізованих оптових ринків. В країнах Свропи і світу вони набули поширення в 50-70-х р. XX ст. Із набуттям незалежності та переходом України на ринкові основи господарювання постала необхідність розвитку інфраструктури аграрного ринку, в якій однією з центральних ланок $є$ оптові підприємства. Їх будівництво потрібно було почати 3 нуля, підвівши для цього законодавчу і правову базу. При нестачі державних фінансових ресурсів виникає необхідність залучення до цього процесу приватного капіталу. В певній мірі це дозволяє зробити існуюча законодавча база. Для практичного втілення і використання механізму залучення фінансових і матеріальних ресурсів у розбудову мережі ОРСП потрібні певні моделі (механізми), які використовуються в світовій практиці.

Метою нашої роботи є дослідження напрямків діяльності ОРСП як форми підприємницької діяльності та висвітлення світового досвіду у використанні найпоширеніших моделей (механізмів) на основі державно-приватного партнерства.

\section{Матеріал і методи досліджень}

Матеріалом для дослідження були існуючі в Україні Закони, законодавчі акти і постанови, нормативноправові акти, на основі яких проводився відповідний аналіз на предмет пошуку оптимальних варіантів моделей (механізмів) розбудови ОРСП. При цьому враховувався закордонний досвід, а також вітчизняні економічні та суспільно-правові умови.

\section{Результати та їх обговорення}

Основною засадою функціонування оптових підприємств на ринку $\epsilon$ організаційно-господарська незалежність, самостійність і свобода вибору організаційно-правової форми, спеціалізації та асортиментного профілю. В.В. Апопій, С.Г. Бабанко та інші (Apopiy et al., 2008) розглядають оптову торгівлю (а оптові торгові підприємства є суб“єктами ії діяльності) як роль торгового посередника між виробниками готової продукції та іiі роздрібними продавцям.

Кількість підприємств оптової торгівлі в Україні 3 розрахунку на 10 тис. осіб на початку 90-х років $\mathrm{XX}$ ст. була в десятки разів меншою, ніж у розвинутих країнах. Так, в Україні цей показник становив на 10 тис. осіб 0,4 підприємства, тимчасом як в США 15,7, Франції - 15,1, Німеччині - 13,0, Італії - 16,0, Нідерландах - 15,8, Великобританії - 7,1 [3,с.78 ]. Варто зазначити, що при командно-адміністративній системі товари - засоби виробництва - не входили в систему оптового товарообороту і надходили за плановою розподільчою рознарядкою. Спостерігався дефіцит самих споживчих товарів, а отже - і потреби в місцях їх зберігання (складах, сховищах). Оптових ринків сільськогосподарської продукції взагалі не існувало, а їх функцію виконували періодичні колгоспні ринки.

«Підприємства зародилися 3 торгівлі (комерції)»це твердження наведене Ю. Губені (Gubeni, 2012) 
підкреслює сутність зародження підприємництва як форми людської діяльності в сфері обігу. Майже вся підприємницька діяльність передбачає реалізацію товарів або послуг. Біля 75\% зареєстрованих підприємств займається торгівлею як видом їх діяльності. В сучасному законодавстві України підприємництво розглядається як частина господарської діяльності. Господарська діяльність - це діяльність суб'єктів господарювання у сфері суспільного виробництва, спрямована на виготовлення та реалізацію продукції, виконання робіт чи надання послуг вартісного характеру, що мають цінову визначеність. Господарська діяльність - це цілеспрямована діяльність для задоволення потреб і вона має стадії: виробництва, розподілу, обміну, споживання (Gubeni, 2012). Господарська діяльність може здійснюватися 3 метою одержання прибутків (комерційна діяльність) та без мети одержання прибутку (неприбуткова діяльність).

Відповідно до Господарського кодексу (Gospodarchyj kodeks Uktainy, 2003) під господарсько-торговельною діяльністю слід розуміти діяльність, що здійснюється суб'єктами господарювання у сфері товарного обміну, спрямована на реалізацію продукції виробничо-технічного призначення і виробів народного споживання. Залежно від ринку (внутрішнього чи зовнішнього) в межах якого здійснюється товарний обіг, господарсько-торговельна діяльність виступає як внутрішня чи зовнішня торгівля. Така діяльність може здійснюватися суб'єктами господарювання в таких формах:

- матеріально-технічне постачання і збут;

- енергопостачання;

- заготівля;

- оптова торгівля;

- роздрібна торгівля і громадське харчування;

- продаж і передача в оренду засобів виробництва;

- комерційне посередництво у здійсненні торговельної діяльності;

- інша допоміжна діяльність щодо забезпечення реалізації товарів (послуг) у сфері обігу.

Особливу увагу Господарський кодекс приділяє укладанню господарських договорів на біржах, ярмарках та публічних торгах, де застосовуються загальні правила їх укладання на основі вільного волевиявлення з урахуванням нормативно-правових актів, якими регулюється діяльність відповідних бірж, ярмарків та публічних торгів. Існує низка постанов і наказів, які регулюють питання створення та діяльність оптових ринків сільськогосподарської продукції (надалі ОРСП). Це, зокрема, Постанова Кабінету Міністрів України «Про затвердження Порядку набуття юридичною особою статусу оптового ринку сільськогосподарської продукції» від 11.02.2010 № 141; Наказ ринків сільськогосподарської продукції» від 19.02.2010 № 73 та інші акти.

Варто зазначити, що через декларативність та загальність Закону необхідне створення нових нормативно-правових актів для врегулювання питань, які постають в процесі будівництва та експлуатації ринків. До першочергових завдань, які вимагають регулювання, відносяться:
- порядок створення та функціонування мережі ОРСП;

- взаємодія оптових ринків, що включає в себе: критерії участі, процедуру та місце проведення торгів;

- продаж та контроль за продукцією (якість, зберігання, транспортування продукції;

- розміщення інфраструктури мережі ОРСП;

- приватно-публічне партнерство. Фінансування діяльності;

- інвестування, включаючи залучення іноземних інвестиції;

- оподаткування та запровадження податкових пільг;

- контроль за діяльністю мережі ОРСП;

- забезпечення державних гарантій та державної політики підтримки.

Як підприємницька структура оптовий ринок може мати різноманітні організаційно-правові форми.

Об’єднання у складі виробників і споживачів агропромислової продукції матимуть взаємний інтерес: мобілізація кредитних ресурсів споживачів змогла б авансувати виробництво сільськогосподарської продукції, а продаж цієї продукції повертав би кредитні кошти залученим структурам. У результаті це оптимізувало б грошові потоки і дало би змогу обійтися без кредитів комерційних банків із їх «позахмарними» кредитними ставками.

Європейською та світовою практикою накопичений певний досвід в побудові та функціонуванні оптових ринків у різних економічних та соціальноправових умовах, який може бути використаний в Україні. 3 економічних умов, які стосуються України, це - недостатність фінансових ресурсів для формування мережі ОРСП; приватний партнер може гарантувати послуги більш високої якості та реалізувати інноваційний підхід до проектів зі створення ОРСП.

Зі сторони соціально-правових умов не повинно бути законодавчих обмежень для залучення сторонніх компаній з досвідом організації подібних проектів. В Україні прийнятий Закон «Про державно-приватне партнерство» (надалі - ДПП), який дозволяє виокремити два способи фінансування: державне і приватне. Хоча якихось суттєвих правових обмежень не існує, однак усі проекти ОРСП з використанням механізму ДПП наштовхуються як на недосконалу правову базу ДПП, так і на відсутність організацій з досвідом розробки проектів та організації розбудови ОРСП. В Україні певний невеликий досвід мають 2-3 компанії, але цього явно недостатньо. Тому залучення іноземних компаній не уникнути. Використання державою приватних компаній не повинно викликати протидії у суспільстві. Для цього приватний партнер може, наприклад, гарантувати нові робочі місця та економічне зростання в регіоні. Водночас недосконале законодавство, непублічність діяльності ОРСП створюють підгрунтя для встановлення монопольного контролю особами приватного права над мережею ОРСП. Це своєю чергою, може привести до конфлікту суспільних та приватних інтересів, до втрати первісної сутності ОРСП як суб'єкта, що створює суспільне благо. 
До державного способу фінансування включається і фінансування 3 місцевих бюджетів, яке часто назива- ють ще муніципальним фінансуванням, фінансуванням територіальних громад.

Найбільш поширені світові моделі (механізми) ДПП при розбудові мережі ОРСП

\begin{tabular}{|c|c|}
\hline Назва моделі & Опис моделі \\
\hline 1 & 2 \\
\hline $\begin{array}{l}\text { BOT (Build, Operate, Transfer - будівництво- } \\
\text { експлуатація / управління - передача) }\end{array}$ & $\begin{array}{l}\text { Цей механізм головним чином використовується у концесіях. ОРСП } \\
\text { створюється за рахунок концесіонера, який після завершення будівниц- } \\
\text { тва отримує право на експлуатацію ОРСП на термін, цо забезпечить } \\
\text { окупність вкладених ресурсів. Потім ОРСП передається державі. Кон- } \\
\text { цесіонер отримує право використання, але не володіння ОРСП, влас- } \\
\text { ником якого є держава. }\end{array}$ \\
\hline $\begin{array}{l}\text { BOОТ (Build,Own, Operate, Transfer - будів- } \\
\text { ництво - володіння - експлуатація / управ- } \\
\text { ління - передача). }\end{array}$ & $\begin{array}{l}\text { У цьому випадку приватний партнер отримує повноваження не тільки } \\
\text { користування а й володіння ОРСП на термін угоди, після чого він пере- } \\
\text { дається державі (муніципалітетету). }\end{array}$ \\
\hline $\begin{array}{l}\text { BTO (Build ,Transfer, Operate - будівництво - } \\
\text { передача - експлуатація / управління) }\end{array}$ & $\begin{array}{l}\text { Цей механізм передбачає передачу ОРСП державі одразу після завер- } \\
\text { шення будівництва. Після цього переходить у користування до приват- } \\
\text { ного партнера, але без права власності (володіння і розпорядження). }\end{array}$ \\
\hline $\begin{array}{l}\text { BOT (Build,Own, Operate - будівництво - } \\
\text { володіння - експлуатація / управління) }\end{array}$ & $\begin{array}{l}\text { У цьому випадку створений ОРСП після завершення дії угоди про } \\
\text { ДПП не передається державі (муніципалітету), а знаходиться у власно- } \\
\text { сті приватного партнера як інвестора. }\end{array}$ \\
\hline $\begin{array}{l}\text { BOMT (Build, Operate, Maintaine,Transfer - } \\
\text { будівництво - експлуатація / управління - } \\
\text { обслуговування - передача) }\end{array}$ & $\begin{array}{l}\text { У цій моделі акцент робиться на відповідальність приватного партнера } \\
\text { за утримання створеного ним ОРСП, в тому числі поточний ремонт. }\end{array}$ \\
\hline $\begin{array}{l}\text { DBOOT (Design,Build,Own, Operate, Transfer } \\
\text {-проектування - будівництво - володіння - } \\
\text { експлуатація / управління - передача) }\end{array}$ & $\begin{array}{l}\text { Особливість цієї моделі в тому, що приватний партнер несе відповіда- } \\
\text { льність не тільки за будівництво ОРСП, а й за його проектування. }\end{array}$ \\
\hline $\begin{array}{l}\text { DBFO (Design,Build,Finance, Operate - проек- } \\
\text { тування - будівництво - фінансування - } \\
\text { експлуатація / управління) }\end{array}$ & $\begin{array}{l}\text { В угодах про ДПП спеціально обумовлюється відповідальність за } \\
\text { фінансування будівництва ОРСП. }\end{array}$ \\
\hline
\end{tabular}

Бізнес-модель оптового ринку сільськогосподарської продукції*

\begin{tabular}{|l|l|}
\hline Ключова діяльність & $\begin{array}{l}\text { 1. Управління інфраструктурою та нерухомістю; 2.Маркетингова та рекламна } \\
\text { діяльність }\end{array}$ \\
\hline Ціннісна пропозиція & 1. Свропейський стандарт оптової торгівлі; 2. Потік без посередників; \\
& 3. Все в одному місці; 4. Ціна дня; 5. Зберігання запасів; \\
6. Інформаційно-консультаційна підтримка
\end{tabular}

* Розробка автора

При державному фінансуванні будівництво ОРСП і його експлуатація фінансується з бюджету, а прива- тний інвестор вкладає інвестиції в проект за рахунок державних субсидій. При приватному фінансуванні 
інвестор окуповує свої видатки за рахунок користувачів послугами ОРСП.

Для українського бізнесу право власності на створений у ході реалізації ДПП оптовий ринок $є$ ключовим. Перехід права власності до держави після завершення договору ДПП використовується досить часто, тому в такому випадку держава повинна гарантувати приватним партнерам цілісність вкладених в ОРСП інвестиції. У різних регіонах застосування тої чи іншої моделі створення ОРСП з використанням механізму ДПП в частині переходу права власності має вирішуватись окремо.

Є різноманітні форми організації (моделі) ДПП для створення ОРСП, в яких відображається спосіб фінансування ДПП, перехід права власності на створений ОРСП, а також участь державного та приватних партнерів на кожному етапі циклу проекту.

Модель «ВОТ» використовується головним чином за договором концесії, за чинним в Україні законодавством об'єкти комунальної власності у формі земельних ділянок, споруд тощо можуть бути передані в концесію. Проте ця форма (концесії) не знаходить в Україні практичного використання. Специфіка українського бізнесу полягає в тому, що партнери - приватні компанії - віддають перевагу моделям, де вони виступають не тільки як розпорядники, а й як власники, що забезпечує їм можливість одержувати максимальні прибутки. 3 цього погляду привабливою $є$ модель «ВОО».

Вибір моделі спорудження ОРСП на основі державно-приватного партнерства та іiі втілення значною мірою залежить від ключових партнерів: міжнародних фінансових організації, органів місцевого самоврядування, інвесторів, а функціонування - від діяльності всіх складових компонентів прийнятої бізнесмоделі оптового ринку, варіант якої подано в таблиці 2.

Сучасний оптовий ринок сільськогосподарської продукції це - не просто місце продажу-купівлі продукції, а складний торгово-логістичний центр, який поєднує в собі багатопрофільні напрями діяльності, які стосуються виробничої, збутової, інформаційноаналітичної, маркетингової, природо-охоронної та інших видів діяльності.

\section{Висновки}

1. Оптові ринки сільськогосподарської продукції являють собою спеціалізовану форму господарськоторгівельної підприємницької діяльності, яка відповідає всім нормативно-правовим вимогам, обумовленим
Господарським кодексом, Законами і законодавчими актами та Постановами.

2. Розбудова мережі оптових ринків сільськогосподарської продукції в Україні відбувається в умовах недостатніх державних фінансових ресурсів. У зв'язку з цим виникає необхідність використати приватний капітал та інвестиції в рамках Закону «Про державно-приватне партнерство», застосувавши для цього набутий європейський та світовий досвід використання відповідних моделей (механізмів) при залученні фінансових та матеріальних ресурсів. Виникає необхідність доопрацювання вищеназваного Закону в напрямі удосконалення нормативно-правової бази щодо оптових ринків, залучення іноземних і внутрішніх інвестицій та іноземних компаній, які мають досвід в розбудові оптових ринків.

Перспективи подальших досліджень. Розбудова мережі оптових ринків сільськогосподарської продукції та їх діяльність вимагають подальших розробок в напрямі залучення зовнішніх інвестицій та внутрішнього капіталу через різноманітні форми державноприватного партнерства та ширшої участі в них виробничих і переробних структур.

\section{Бібліографічні посилання}

Apopiy, V.V., Babenko, S.G., Goncharuk, Y.P. (2008). Komertsiyna diyalnist. K: Znannya (in Ukrainian).

Austen, J. (2006). Programa stvorennia optovyh rynkiv v Ukraini. Agrooglia: ovochi i frukty. 7, 36-38 (in Ukrainian).

Belyavtsev, M.I., Shestopalov, L.V. (2005). Infrastruktura tovarnogo rynku. K.: Tsentr navchalnoyi literatury (in Ukrainian).

Gospodarchyj kodeks Uktainy (2003). K.: Atika (in Ukrainian).

Gubeni, Y.E. (2012). Pidpryuemnytstvo. Navchalyj posibnyk. Lviv: NVF «Ukrainski tehnologii» (in Ukrainian).

Zakon Ukrainy (2009). Pro optovi rynky silskogospodarskoi produktsii. Vidomosti Verkhovkoyi Rady Ukrainy. 51 (in Ukrainian).

Zakon Ukrainy (2012). Pro derzhavno-pryvatne partnerstvo. 2402-V.I. (in Ukrainian).

Muzyka, P.M., Domanska, N.A. (2014). Optovi rynky silskogospodarskoi produktsii: Strategia pobudovy i funktsionuvannia. Naukovyj visnyk LNUVMBT imeni S.Z. Gzhytskogo. 16, 3(60), 140-147 (in Ukrainian).

Received 11.09.2017

Received in revised form 9.10.2017 Accepted 13.10.2017 